\section{PROMOSI KESEHATAN \\ TENTANG MEMPERSIAPKAN \\ GENERASI DALAM 1000 HARI \\ PERTAMA \\ KEHIDUPAN PADA IBU HAMIL}

\author{
Hetty WA Panggabean ${ }^{1}$,Marni \\ Siregar $^{2}$ \\ 1,2 Akademi Kebidanan Tarutung \\ Email : \\ hettypanggabean54@gmail.com
}

\begin{abstract}
Background Every parent wants their children to grow up healthy. For this reason, mothers and fathers must pay attention to children's nutrition, especially at an important time in their lives, namely, the First Thousand Days of Life (HPK) or what is commonly called the Golden Period. At this time, the mother must meet her daily nutritional intake so that the development of the fetus's organs and brain is perfect. Fulfillment of nutrition for children in the first 1000 days of life is very important. Because if the nutritional intake is not met, the impact on children's development will be permanent. The impact can be in the short term and long term, as a result of malnutrition during fetal period (pregnancy) and early childhood. The short-term impact will interfere with brain development, growth, and metabolic programming. In Simatupang Village, the Muara Community Health Center Work Area, there were 15 pregnant women in October 2018. Based on data obtained in September 2018, it is
\end{abstract}

known that exclusive breastfeeding in the Muara Puskesmas area is still low $(37 \%)$.

Purpose of this PKM activity is to increase public knowledge, especially pregnant women and to determine growth and development in the form of height and weight of toddlers.

Method begins with coordination with the Muara Puskesmas, the Village Head, the Simatupang Village Midwife about counseling for pregnant women and examining the growth and development of toddlers.

Results Obtained from 15 pregnant women, there were 3 people $(20 \%)$ who experienced the risk of pregnancy and from the results of the growth and development of underfives including height and weight for 30 toddlers, there were 3 (16.67) toddlers with height and weight. not according to his age.

Conclusion Health promotion by conducting counseling and examinations to pregnant women has been carried out. The results of antenatal care found that $(20 \%)$ had a risk of pregnancy. Examination of height and weight to male and female toddlers found $16.67 \%$ experienced height and weight not according to their age.

Keywords; The first 1000 days of

life, pregnant women

PENDAHULUAN 
Setiap orangtua pasti ingin anaknya tumbuh sehat. Untuk itu, Ibu dan Ayah wajib memperhatikan nutrisi anak, terutama di masa penting dalam kehidupannya, yaitu, Seribu Hari Pertama Kehidupan (HPK) atau yang biasa disebut Golden Period. Seribu Hari Pertama Kehidupan dimulai sejak terjadinya pembuahan di dalam kandungan, hingga anak berusia 2 tahun. Seribu hari tersebut terdiri atas 270 hari ( 9 bulan) selama kehamilan dan 730 hari (2 tahun) kehidupan sejak bayi dilahirkan. Seribu Hari Pertama Kehidupan sangat penting karena ini adalah masa pertumbuhan dan perkembangan seluruh organ dan sistem tubuh. Pada saat dilahirkan, bayi mempunyai organ yang hampir semuanya telah selesai terbentuk, dan organ tersebut akan terus berkembang sampai ia berusia 2 tahun.

Pada masa ini, ibu harus memenuhi asupan nutrisi hariannya agar perkembangan organ dan otak janin sempurna. Karena jika tidak sempurna, maka efeknya permanen. Artinya, bila perbaikan gizi dilakukan setelah melewati masa 1000 HPK, maka perbaikannya tidak terlalu membawa perubahan besar. Sebaliknya jika dilakukan pada masa 1000 HPK, terutama saat berada dalam kandungan, maka efek perbaikannya bermakna. Beberapa nutrisi yang perlu dipenuhi pada masa 1000 Hari Pertama Kehidupan adalah, asam folat, kalsium, fosfor, magnesium, vitamin $\mathrm{D}$, protein, zat besi, Omega 3\&6, DHA, serta kolin. Sama seperti berinvestasi, kesehatan buah hati yang diidamkan bisa dibentuk maksimal jika Ibu dan Ayah senantiasa 'menabung' dan memperhatikan nutrisi sejak dini.

Gangguan yang terjadi pada periode ini akan berdampak pada kelangsungan hidup dan tumbuh kembang anak yang bersifat permanen dan berjangka panjang sehingga sejak dalam kandungan pada masa hamil, setelah lahir sampai anak berusia 2 tahun harus diperhatikan.

Seribu hari pertama kehidupan ini terdiri dari 270 hari selama kehamilan dan 730 hari pada 2 tahun pertama kehidupan Pada 8 minggu pertama di dalam kandungan: Terbentuknya cikal bakal janin yang akan berkembang menjadi otak, hati, 
jantung, ginjal, tulang, tangan atau lengan, kaki, dan organ tubuh lainnya.

Pada 9 minggu hingga lahir: Pertumbuhan dan perkembangan lebih lanjut dari organ tubuh hingga siap untuk hidup di dunia baru, yakni di luar kandungan ibu. Setelah lahir: Sebagian organ masih berkembang sampai usia 2 - 3 tahun, misalnya otak.

Pemenuhan gizi pada anak di 1000 Hari Pertama Kehidupan menjadi sangat penting. Sebab jika tidak dipenuhi asupan nutrisinya, maka dampaknya pada perkembangan anak akan bersifat permanen. Dampaknya bisa berupa jangka pendek dan jangka panjang, sebagai akibat dari gangguan gizi pada masa janin (kehamilan) dan anak usia dini. Dampak jangka pendeknya, akan mengganggu perkembangan otak, pertumbuhan, dan metabolik programing. Sementara dampak jangka panjangnya akan memengaruhi tingkat kecerdasan, perkembangan kognitif, pendidikan rendah, stunting (pendek atau sangat pendek), terjangkit penyakit tidak menular (PTM), yakni hipertensi, diabetes, jantung koroner, stroke, dan obesitas

Hal inilah yang mendasari institusi perlu memberikan penyuluhan mengenai 1000 hari pertama kehidupan pada ibu hamil di Desa Simatupang Wilayah Kerja Puskesmas Muara yang berjumlah 15 orang pada bulan Oktober. Berdasarkan data yang diperoleh pada bulan September 2018 diketahui bahwa pemberian ASI eksklusif di wilayah Puskesmas Muara masih rendah (37\%). Dari kejadian tersebut, Akademi Kebidanan Tarutung merasa terlibat dalam upaya peningkatan pengetahuan masyarakat melalui penyuluhan mengenai 1000 hari pertama kehidupan dalam mempersiapkan generasi yang sehat, cerdas dan berakhlak mulia.

\section{METODE}

Teknik yang digunakan dalam menyampaikan materi penyuluhan melalui ceramah dengan menggunakan alat bantu multimedia berupa laptop dan LCD. Berdasarkan analisis masalah yang diperoleh sesuai dengan hasil anamnesa pendahuluan kepada ibu hamil maka 
dapat teridentifikasi masalah kurangnya pengetahuan tentang penting kehidupan 1000 HPK pada bayi. Penyelesaian masalah yang akan dilakukan yaitu dengan Tri Darma Perguruan Tinggi dalam hal ini adalah PKM yaitu Ibu Hamil di Desa Simatupang Wilayah Kerja Puskesmas Muara Kecamatan Muara Kabupaten Tapanuli Utara. Untuk meningkatkan pengetahuan ibu hamil dilakukan penyuluhan tentang mempersiapkan generasi dalam 1000 hari pertama kehidupan kepada ibu hamil.

Dalam memberikan penyuluhan pada ibu hamil, kita dapat memberikan pengetahuan dengan analisa masalah kesehatan melalui langkah berikut :

1. Mengenal Masalah Kesehatan

Menjelaskan pentingnya 1000 hari pertama kehidupan yaitu masa pertumbuhan dan perkembangan seluruh organ dan sistem tubuh bayi di bawah dua tahun. Seribu hari pertama kehidupan adalah saat terpenting bagi anak. Ketika sperma dan sel telur bertemu, itulah hari pertama dalam rentang 1000 Hari Pertama Kehidupan manusia. Sejak saat itu, pentingnya pemenuhan gizi bagi perkembangan janin didalam kandungan. Bahkan, sebenarnya, pemenuhan gizi harus dilakukan sebelum pernikahan. Begitu pula pemenuhan gizi setelah lahir, hingga anak tersebut ulang tahun yang ke dua. Itulah masa penentuan kesehatan dan kecerdasan seseorang. Beberapa ahli mengatakan bahwa periode umur anak diabawah 2 tahun dikenal dengan "Periode Emas" atau "Window Opportunity".

Jika demikian adanya, mendorong anak dan remaja untuk mengkonsumsi makanan bergizi tidak lebih utama dibanding apa yang dimakan ibu saat hamil. Gizi makanan selama kehamilan inilah yang mempengaruhi fungsi memori, konsentrasi, pengambilan keputusan, intelektual, mood, dan emosi seorang anak di kemudian hari.

2. Mengenal Penyebab Masalah Kesehatan

Menjelaskan pengertian dan tahapan 1000 hari pertama kehidupan, menjelaskan pentingnya pemenuhan gizi selama kehamilan, menjelaskan pentingnya ASI Eksklusif selama 6 bulan pertama pada bayi, dan 
pemberian MP ASI, PASI sampaoi bayi berusia 2 tahun, menjelaskan teknik menyusui dan posisi yang benar saat menyusui. Hal ini perlu disarankan kepada ibu, dengan memberikan penjelasan bagian yang penting untuk mengatasi masalah.

3. Mengenal Sifat Masalah Kesehatan Menjelaskan dampak kekurangan gizi pada ibu hamil akan memberikan dampak buruk pada skor IQ (kecerdasan) anak. Ibu yang menderita kekurangan zat iodium selama kehamilan akan menghambat perkembangan otak dan janin dan mengakibatkan kehilangan 10 IQ poin. Kekurangan energy protein pada ibu hamil yang di sebabkan oleh kekurangan makanan bergizi dan infeksi akan menyebabkan gangguan fungsi kognitif dan perkembangan bayi juga akan mengalami kehilangan skor IQ sebesar 10 poin.

$$
\text { Rangkaian kegiatan }
$$

Pengabdian Masyarakat ini dimulai dari Usul Proposal Pengabdaian Masyarakat ke penanggung jawab kegiatan Pengabdian Masyarakat di Akademi Kebidanan Tarutung. Kemudian Proposal Pengabdian
Masyarakat di evaluasi oleh tim penanggung jawab kegiatan. Pelaksanaan kegiatan pengabdian kepada masyarakat dilakukan setelah mendapat persetujuan dari penanggung jawab kegiatan. Untuk kelancaran kegiatan pengabdian, penanggung jawab kegiatan memantua pelaksanaan kegiatan pengabdian masyarakat.

Tahapan Kegiatan pengabdian yang dilakukan di Desa Simatupang Wilayah Kerja Puskesmas Muara Kecamatan Muara adalah:

a) Peninjauan Lapangan/lokasi sekaligus pengumpulan data dan orientasi lokasi

b) Pengurusan ijin kegiatan ke Puskesmas Muara

c) Melakukan koordinasi, menjelaskan maksud serta tujuan kegiatan dengan Kepala dan Bidan Desa Simatupang Wilayah Kerja Puskesmas Muara.

d) Mempersiapkan bahan untuk kegiatan, baik materi penyuluhan dan susu Laktamil pada ibu hamil.

e) Melakukan kegiatan penyuluhan pada ibu hamil 
f) Pemberian susu hamil pada ibu hamil.

g) Pembagian biskuit kepada Balita

\section{HASIL DAN PEMBAHASAN}

Hasil

Kegiatan pengabdian masyarakat tentang pemeriksaan ibu hamil, dan pemeriksaan tumbuh kembang Balita telah dilaksanakan pada hari Minggu tanggal 18 Februari 2019, dengan perincian jadwal sebagai berikut.

\section{Penyuluhan dan Pemeriksaan}

\section{Pada Ibu Hamil}

Sebanyak 15 orang ibu hamil datang Puskesmas Muara untuk penyuluhan dan melakukan pemeriksaan kehamilan sekaligus untuk menghadiri kegiatan pengabdian masyarakat yang telah direncanakan.

a. Penyuluhan tentang kehamilan dilaksanakan selama 20 menit

Materi penyuluhan tentang kehamilan yang meliputi pengertian kehamilan, tandatanda kehamilan, kondisi dan kesejahteraan ibu hamil, menjelaskan pentingnya pemenuhan gizi selama kehamilan, menjelaskan pentingnya ASI Eksklusif selama 6 bulan pertama pada bayi, menjelaskan teknik menyusui dan posisi yang benar saat menyusui dan tanda-tanda bahaya kehamilan.

b. Setelah selesai penyuluhan dilakukan pemeriksaan fisik pada ibu hamil untuk mengetahui kondisi ibu hamil dan janinnya. Seluruh ibu hamil dan janin dalam kondisi sehat walau ada 2 orang dengan tekanan dari 140/90 $\mathrm{mmHg}$ dan 1 orang post SC. Team memberikan penjelasan kepada ibu hamil dengan tekanan darah 140/90 mmHg agar ibu menjaga kesehatannya dengan istirahat 1-2 jam pada siang hari dan 67 jam pada malam hari. Ibu diberi penjelasan agar lebih banyak mengkonsumsi sayur dan buah serta mengurangi makanan yang mengandung garam berlebihan. Terakhir ibu diberi penjelasan jika 
menemukan tanda-tanda

bahaya seperti kepala pusing

dan tidak hilang saat istirahat,

pandangan mata tiba-tiba

kabur maka ibu hamil

sesegera mungkin untuk

memeriksakan diri ke bidan. c. Untuk menambah nutrisi pada ibu hamil, tim pengabdian masyarakat memberikan susu ibu hamil untuk dikonsumsi di rumah.

Hasil pemeriksaan pada ibu hamil dijelaskan pada tabel di bawah ini :

Tabel.1 Hasil Pemeriksanaan Ibu Hamil di Desa Simatupang Wilayah Kerja

Puskesmas Muara Kecamatan Muara Kabupaten Tapanuli Utara

\begin{tabular}{cccc}
\hline No & KONDISI & F & \% \\
\hline 1 & Mengalami Risiko & 3 & 20 \\
2 & Tidak mengalami Risiko & 12 & 80 \\
& Jumlah & $\mathbf{1 5}$ & $\mathbf{1 0 0}$ \\
\hline
\end{tabular}

Sumber : Data Primer, 2018

Pada tabel di atas mengalami risiko kehamilan sebesar menunjukkan, hasil pemeriksaan ibu $12(80 \%)$.

hamil pada umumnya ibu hamil tidak

\section{Pemeriksaan Tumbuh Kembang Balita}

Tabel 2 Karakteristik Jenis Kelamin Balita di Desa Simatupang Wilayah Kerja Puskesmas Muara Kecamatan Muara Kabupaten Tapanuli Utara

\begin{tabular}{|c|c|c|c|}
\hline No & JENIS KELAMIN & $\mathbf{F}$ & $\%$ \\
\hline 1 & Laki - laki & 18 & 60 \\
\hline 2 & Perempuan & 12 & 40 \\
\hline & Jumlah & 30 & 100 \\
\hline
\end{tabular}

Sumber : Data Primer, 2018 
Pada tabel di atas yang ada di Desa Simatupang Wilayah menunjukkan bahwa karakteristik Kerja Puskesmas Muara berdasarkan jenis kelamin Balita pada umumnya berdasarkan tinggi badan dan berat adalah laki laki sebanyak 18 (60\%) badan. Di bawah ini adalah hasil Balita

Hasil pemeriksaan tumbuh pemeriksaan tinggi badan dan berat badan balita laki - laki dan perempuan :

kembang Balita kepada 30 orang Balita

Tabel 3 Tumbuh Kembang Balita Jenis Kelamin Perempuan di Desa

Simatupang Wilayah Kerja Puskesmas Muara Kecamatan Muara

Kabupaten Tapanuli Utara

\begin{tabular}{ccccc}
\hline No & Nama Balita & Usia (Bulan) & TB (CM) & BB (KG) \\
\hline 1 & A.S & 1 & 49 & 4 \\
2 & T.O & 2 & 58 & 5 \\
3 & T.S & 4 & 62 & 7 \\
4 & C.O & 12 & 74 & 9 \\
5 & D.S & 14 & 77 & 9,5 \\
6 & T.S & 17 & 81 & 10 \\
7 & E.T & 20 & 83 & 10,5 \\
8 & Y.S & 21 & 84 & 11 \\
9 & K.T & 24 & 87 & 12 \\
10 & T.G & 32 & 93 & 14 \\
11 & A.T & 48 & 102 & 17,5 \\
12 & L.O & 60 & 113 & 21
\end{tabular}

Sumber : Data Primer, 2018

Pada tabel di atas dan berat badan Balita Perempuan menunjukkan bahwa tinggi badan adalah dalam keadaan normal. 
Tabel 4 Tumbuh Kembang Balita Jenis Kelamin Laki -laki di Desa

Simatupang Wilayah Kerja Puskesmas Muara Kecamatan Muara

Kabupaten Tapanuli Utara

\begin{tabular}{|c|c|c|c|c|}
\hline No & Nama Balita & Usia (Bulan) & TB (CM) & BB (KG) \\
\hline 1 & A.S & 1 & 49 & 4 \\
\hline 2 & F.S & 1 & 45 & 4,1 \\
\hline 3 & A.R & 3 & 61 & 6 \\
\hline 4 & C.S & 7 & 69 & 7,9 \\
\hline 5 & B.S & 9 & 67 & 7 \\
\hline 6 & A.T & 12 & 75 & 9 \\
\hline 7 & R.S & 14 & 78 & 9,5 \\
\hline 8 & E.S & 15 & 79 & 10,1 \\
\hline 9 & R.O & 24 & 87 & 12 \\
\hline 10 & S.O & 24 & 81 & 9,5 \\
\hline 11 & K.S & 26 & 88 & 12,3 \\
\hline 12 & E.O & 30 & 91 & 12,8 \\
\hline 13 & P.S & 32 & 93 & 13 \\
\hline 14 & G.O & 36 & 96 & 14,5 \\
\hline 15 & V.S & 36 & 96,5 & 14 \\
\hline 16 & D.S & 36 & 96,3 & 14,2 \\
\hline 17 & F.T & 40 & 91 & 12 \\
\hline 18 & B.S & 48 & 103 & 16 \\
\hline 30 & G.T & 60 & 114 & 21,2 \\
\hline
\end{tabular}

Sumber : Data Primer, 2018

Pada tabel di atas dan berat badan yang tidak menunjukkan bahwa ada 3 orang normal atau tidak sesuai dengan yang mengalami tinggi badan usianya. 
Tabel 5 Tumbuh Kembang Balita Perempuan di Desa Simatupang Wilayah

Kerja Puskesmas Muara Kecamatan Muara Kabupaten Tapanuli

Utara

\begin{tabular}{clcc}
\hline No & Tumbuh Kembang & F & N \\
\hline 1 & Normal & 12 & 100 \\
2 & Tidak Normal & 0 & 0 \\
& Jumlah & $\mathbf{1 2}$ & $\mathbf{1 0 0}$ \\
\hline
\end{tabular}

Sumber : Data Primer, 2018

Pada tabel di atas Kembang Balita Perempuan pada menunjukkan bahwa Tumbuh umumnya normal yaitu $100 \%$.

Tabel 6 Tumbuh Kembang Balita Laki - laki di Desa Simatupang Wilayah Kerja Puskesmas Muara Kecamatan Muara Kabupaten Tapanuli Utara

\begin{tabular}{clcc}
\hline No & \multicolumn{1}{c}{ Tumbuh Kembang } & F & N \\
\hline 1 & Normal & 15 & 83,33 \\
2 & Tidak Normal & 3 & 16,67 \\
& $\quad$ Jumlah & $\mathbf{1 8}$ & $\mathbf{1 0 0}$
\end{tabular}

Sumber : Data Primer, 2018

Pada tabel di atas menunjukkan bahwa Tumbuh Kembang Balita Laki - laki ada yang mengalami tinggi dan berat

\section{Pembahasan}

Penyuluhan tentang kehamilan dilaksanakan selama 20 menit. Materi penyuluhan meliputi tentang pengertian kehamilan, tanda- tanda kehamilan, kondisi dan kesejahteraan ibu hamil, menjelaskan pentingnya pemenuhan gizi selama kehamilan, menjelaskan pentingnya ASI Eksklusif selama 6 bulan pertama 
pada bayi, menjelaskan teknik menyusui dan posisi yang benar saat menyusui dan tanda-tanda bahaya kehamilan.

Setelah selesai penyuluhan, berikutnya adalah dengan mealukan pemeriksaan fisik pada ibu hamil untuk mengetahui kondisi ibu hamil dan janinnya. Seluruh ibu hamil dan janin dalam kondisi sehat walau ada 2 orang dengan tekanan dari 140/90 $\mathrm{mmHg}$ dan 1 orang post SC. Team memberikan penjelasan kepada ibu hamil dengan tekanan darah 140/90 $\mathrm{mmHg}$ agar ibu menjaga kesehatannya dengan istirahat 1-2 jam pada siang hari dan 6-7 jam pada malam hari. Ibu diberi penjelasan agar lebih banyak mengkonsumsi sayur dan buah serta mengurangi makanan yang mengadung garam berlebihan. Terakhir ibu diberi penjelasan jika menemukan tandatanda bahaya seperti kepala pusing dan tidak hilang saat istirahat, pandangan mata tiba-tiba kabur maka ibu hamil sesegera mungkin untuk memeriksakan diri ke bidan.

Setelah selesai pemeriksaan ibu hamil, dilanjutkan dengan pemeriksaan tumbung kembang balita yang meliputi pengukuran tinggi badan dan berat badan. Dari hasil yang diperoleh bahwa ada 3 (tiga) orang Balita laki - laki mengalami tinggi dan berat badan tidak sesuai dengan usianya. Kurangnya berat badan pada Balita disebabkan oleh berbagai faktor, antara lain adalah faktor genetik/keturanan, faktor ekonomi, dan faktor gizi, faktor penyakit yang memiliki efek samping penurunan berat badan serta mengkonsumsi obat - obatan yang dapat menyebabkan hilangnya nafsu makan. Salah satu cara untuk mengetahui kesehatan dan pertumbuhan Balita adalah dengan memantau tinggi badan dan berat badan tiap bulan ke Posyandu. Ibu yang memiliki Balita yang tinggi badan dan berat badan tidak sesuai dengan usia anak dijelaskan tentang pemberian makanan dengan gizi seimbang, menganjurkan ibu rutin ke Posyandu tiap bulan dan menyerahkan data Balita tersebut ke Kepala Puskesmas untuk ditindaklanjuti penanganannya. 


\section{UCAPAN TERIMAKASIH}

Terimakasih kepada Kepala

Puskesmas Muara, Bidan Desa

Siamtupang, Kepala Desa

Simatupang, Direktur Akademi

Kebidanan Tarutung, Ibu hamil Desa

\section{KESIMPULAN}

Kesimpulan dari hasil kegiatan pengabdian masyarakat tentang promosi kesehatan tentang mempersiapkan generasi dalam 1000 hari pertama kehidupan pada ibu hamil di Desa Simatupang Wilayah Kerja Puskesmas Muara Kecamatan Muara adalah hasil pemeriksaan pada ibu hamil pada umumnya tidak

\section{DAFTAR PUSTAKA}

Bandiyah, 2009, Masalah Pada Ibu Hamil, Jakarta, PT. Gramedia Pustaka Utama.

Casanas, 2012, Perbedaan Signifikan Tentang Intervensi Hidup Sehat, Jakarta, PT. Gramedia Pustaka Utama.

Evelyn C. Pearce, 2002, Anatomi dan Fisiologi, Jakarta, Gramedia.

E. Albert Reece and John C. Hobbins. Clinical Obstetrics, 2007, The Fetus and Mother. Third
Simatupang dan Ibu yang memiliki Balita di Desa Simatupang serta seluruh pihak yang telah membantu terlaksananya PKM ini dengan lancar khususnya yang tidak bias tim sebutkan satu persatu.

mengalami risiko kehamilan sebanyak 12 orang $(80 \%)$. Walau ada 3 orang (20\%) mengalami risiko yaitu 2 orang mengalami tekanan darah 140/90 $\mathrm{mmHg}$ dan 1 orang riwayat sectio caesarea (SC). Pemeriksaan tumbuh kembang Balita yang meliputi tinggi dan berat badan dimana terdapat 3 orang $(16,67 \%)$ Balita laki - laki dengan tinggi dan berat badan tidak sesuai usianya.

edition, Jakarta, Blackwell Publishing.

F. Garry Cunningham, 2006, Obstetri Williams, Edisi 21, Jakarta, EGC.

Hardiwinato, 2005, Pemeliharaan Kesehatan, Jakarta. PT. Gramedia Pustaka Utama.

Kemenkes RI, 2014, Modul Imunisasi dan Tatalaksana Bayi Baru Lahir, Jakarta, Kemenkes.

Kemenpora, 2007, Senam 1000 Hari Pertama Kehidupan (HPK) Pada Ibu Hamil, Jakarta, 
Dinas Olahraga dan

Pendidikan Prov. DKI Jakarta.

Manuaba dkk., 2006, Pengantar

Kuliah Obstetri, Jakarta, EGC.

Maryam, Siti R, dkk. 2008, Mengenal

Usia Lanjut dan

Perawatannya, Jakarta,

Salemba Medika.

Media Indonesia Nasional, 2009, Meningkatnya Jumlah Ibu Hamil di Indonesia, Jakarta.

Mochtar, 1998, Sinopsis Obstetri, Jakarta, EGC.

Prawirohadjo, 2014, Ilmu Kebidanan, Jakarta, Yayasan Balai Pustaka Sarwono Prawirohadjo.

Sumasajuno, 1995, Peningkatan Kondisi Fisik, Psikologis Maupun Sosial Ibu Hamil, Jakarta, PT. Gramedia Pustaka Utama. 